\title{
Violência e Insegurança Urbana: um Fenómeno em Crescimento ou em Transformação? o Caso da Área Metropolitana de Lisboa
}

Eduardo Viegas Ferreira*

\begin{abstract}
$\mathrm{R}$ relação existente entre a violência urbana e a insegurança revelada nas grandes áreas metropolitanas, tendo em consideração os principais factores que parecem estar subjacentes a essa relação. Tendo como referência alguns dados empíricos disponíveis sobre a área metropolitana de Lisboa, é ainda analisada a evolução recente destes dois fenómenos, bem como um conjunto de estratégias de prevenção que têm vindo a ser desenvolvidas ou que poderão vir a ser accionadas num futuro próximo por forma a atenuar a insegurança que é revelada por um elevado número de actores urbanos.

\section{Palavras-chave: violência e insegurança urbanas; áreas metropolitanas; estratégias de prevenção}

\section{Sobra a Cidade como Espaço de Segurança}

As cidades modernas construíram-se e estruturaram-se, em parte, como o resultado de uma crescente necessidade de protecção e segurança dos corpos e dos bens daqueles que nelas conseguiam ser acolhidos e ser reconhecidos como cidadãos. Os próprios Estados modernos, tal como os conhecemos e concebemos, desenvolveram-se como uma forma de resposta à problemática da violência e da insegurança com ela relacionada. A sua consolidação, em larga medida tornada possível e legítima pela monopolização do direito ao exercício da violência, exterior e interna, como autores como Max Weber (1983) ou Tilly (1985) analisaram e discutiram de forma mais aprofundada, parece ter tido, como um dos seus corolários, quer uma significativa redução dos crimes violentos, quer a conquista do direito universal à protecção e à segurança de pessoas e bens.

- culminar do processo civilizacional, tal como Elias o descreveu (1989), não significou, no entanto, que a violência passível de ser exercida sobre alguns actores, em especial aqueles mais desprotegidos de um ponto de vista institucional, tenha desaparecido. Essa violência, ou o seu potencial, continuou presente nas sociedades europeias, como na portuguesa (M.Vaz, 1998), pelo que parece mais apropriado referirmo-nos a um direito quase universal. Mas sabe-se que pelo menos desde os séculos XVII e XVIII registou-se um contínuo decréscimo da violência, como o demonstraram, entre outros, Lodhi e Tilly (1973: 297-318). Hoffer e Hull (1981) e Beattie (1986), também mostraram que os processos de emergência e de consolidação dos Estados modernos foram acompanhados por menores volumes de crimes violentos contra as pessoas, uma tendência que, aliás, ainda hoje parece manter-se (LaFree e Kick, 1986: 213-236). Saliente-se, no entanto, que esta lenta diminuição da violência não foi acompanhada por uma diminuição dos designados crimes contra bens patrimoniais. Pelo contrário, e como salientou Foucault (1977: 70-71), desde o fim do século XVII que a diminuição dos crimes mais violentos, como os homicídios e as agressões, parece ter sido acompanhada por um aumento dos crimes contra a propriedade.

\footnotetext{
* Licenciado e Mestre em Sociologia. Assistente no Instituto Superior de Polícia Judiciária e Ciências Criminais. Contacto: eduardo.ferreira@pj.pt
} 
Alguns autores como Johnson, E. e Monkkonen (1996) têm defendido que uma análise objectiva da evolução histórica da criminalidade esbarra, invariavelmente, com elementos que são tudo menos objectivos. Estatísticas oficiais, documentos dos tribunais ou das prisões, em todos se pode colocar a marca da subjectividade oficial ${ }^{1}$. Apesar destas limitações, parece evidente que a cidade se tornou menos violenta que os meios rurais, e que entre os séculos XVI e XIX a Europa assistiu a significativas mudanças na estrutura da criminalidade, de um predomínio de crimes violentos para um predomínio de crimes contra a propriedade. Além disso, os elementos disponíveis também indiciam que as tendências criminais de longo prazo em muitos países europeus têm sido, efectivamente, de decréscimo, e não de aumento, dos crimes mais violentos. Apesar da existência de alguns dados empíricos contraditórios, o constante declínio da criminalidade mais violenta, que durante milénios ameaçou os corpos e os domicílios, parece ter efectivamente diminuído significativamente nas sociedades ocidentais e, em particular, nas suas cidades (P. Spierenberg, 1996). Nesta sequência, durante a maior parte do século XX a questão da violência interpessoal acabaria por ser relegada para um lugar secundário enquanto preocupação primordial ou estruturante da maioria dos actores urbanos. Tal parece ter ocorrido porque o longo processo de pacificação dos medos, que culminou na conquista do direito quase universal à segurança de pessoas e bens também induziu, num primeiro momento, o recentramento das preocupações nos riscos de guerras entre Estados e, num segundo momento e sobretudo no final dos anos 60, nas ameaças colocadas pela estagnação ou recessão económica. Apesar de, nos anos 70, a insegurança económica, derivada da ameaça de desemprego ou de subemprego, ter motivado inúmeras manifestações de violência ${ }^{2}$, esta foi invariavelmente entendida como a expressão mais visível de uma frustração ou de uma resposta colectiva às injustiças sociais acentuadas pela crise económica (Lagrange e Zauberman, 1991: 243). E, por esse motivo, compreensível, relativamente desculpável e, conse- quentemente, dificilmente geradora de uma elevada insegurança.

O desenvolvimento, nos Estados Unidos, dos conceitos de violence, de civil desobedience e de domestic turmoil visou precisamente descrever e explicar esses fenómenos, então entendidos como a manifestação de uma revolta colectiva porque, na sua essência, possuíam uma função expressiva e política e dificilmente podiam ser entendidos como sendo motivados pelo lucro, pela vingança ou por paixões individuais (Lagrange Zauberman, 1991: 235). As manifestações desta violência colectiva, de que as cidades foram, e ainda são, o palco privilegiado, foram por isso compreendidas, e não raras vezes desculpadas e apoiadas pela maioria dos actores urbanos, porque eram uma forma de ultrapassar os riscos associados à crescente aleatoriedade e imprevisibilidade das estruturas e dos movimentos económicos e sociais e, não menos importante, a aparente incapacidade do Estado, e da maioria das instituições tradicionais, para explicar, prever e, por isso, controlar, todos os novos riscos que ameaçavam a maioria dos actores urbanos.

\section{Violência, Crime e Insegurança Urbana}

A insegurança relacionada com o receio do crime violento só voltaria a assumir-se como uma questão central na maioria dos países ocidentais na década de 90. A criminalidade começou a ser detectada, na maioria das sondagens à opinião pública (Esteves, 1999), como um dos problemas mais graves e com consequências mais negativas para a qualidade de vida nas cidades. O caso dos Estados Unidos torna-se paradigmático quando se constata (Garofalo, 1981), logo no início dos anos 80, que o receio do crime estava presente no quotidiano de uma elevada percentagem de actores urbanos, influenciando as suas relações interpessoais, os seus hábitos e as suas próprias decisões em termos, por exemplo, de mobilidade laboral ou residencial ${ }^{3}$. A maioria dos actores urbanos americanos parecia viver sob a permanente ameaça de ser vítima de

\footnotetext{
${ }^{1}$ É exactamente devido às insuficiências e distorções que são introduzidas pelos números oficiais da criminalidade que optámos invariavelmente pelo recurso aos resultados obtidos por inquéritos de vitimação. Ver, a este propósito e por exemplo, Robert, P. et al. (1999), “Mesurer le crime. Entre statistiques de police et enquêtes de victimation", Revue Française de Sociologie, n. ${ }^{\circ}$ XL (2)

2 A radicalização, no início dos anos 70 e em países como a Alemanha, a Itália, a Grã-Bretanha e, em certa medida, a Espanha, das violências terroristas, invariavelmente direccionada a alvos políticos, constituiu uma manifestação extrema deste processo.

3 Fenómeno que levou vários autores a considerar que grande parte da intensa mobilidade americana se podia reconduzir, em grande parte, a uma mobilidade motivada pelo receio do crime - cf. Dias e Andrade (1984) e Davis (1998).
} 
criminosos e essa ameaça era, aparentemente, estruturante da sua vida quotidiana e, não raras vezes, estruturante da própria cidade.

Embora com manifestações menos extensas e profundas, este fenómeno também começou a reemergir na generalidade dos outros países ocidentais. No caso português, e em particular na área metropolitana de Lisboa, a criminalidade começou a ser crescentemente referenciada, em inquéritos de vitimação, como um dos três problemas mais graves existentes (Gráfico n. ${ }^{\circ} 1$ ). Comparativamente a outros riscos, como o desemprego, a diminuição do poder de compra, a doença ou a inexistência de reformas ou pensões de velhice, o receio de vitimação criminal parece ter voltado a assumir um lugar cada vez mais preponderante $e^{4}$, aparentemente, estruturante das formas de sentir e viver a cidade ${ }^{5}$.

Gráfico n. ${ }^{\circ} 1$ - Preocupação com a criminalidade e a insegurança revelada na área metropolitana de Lisboa

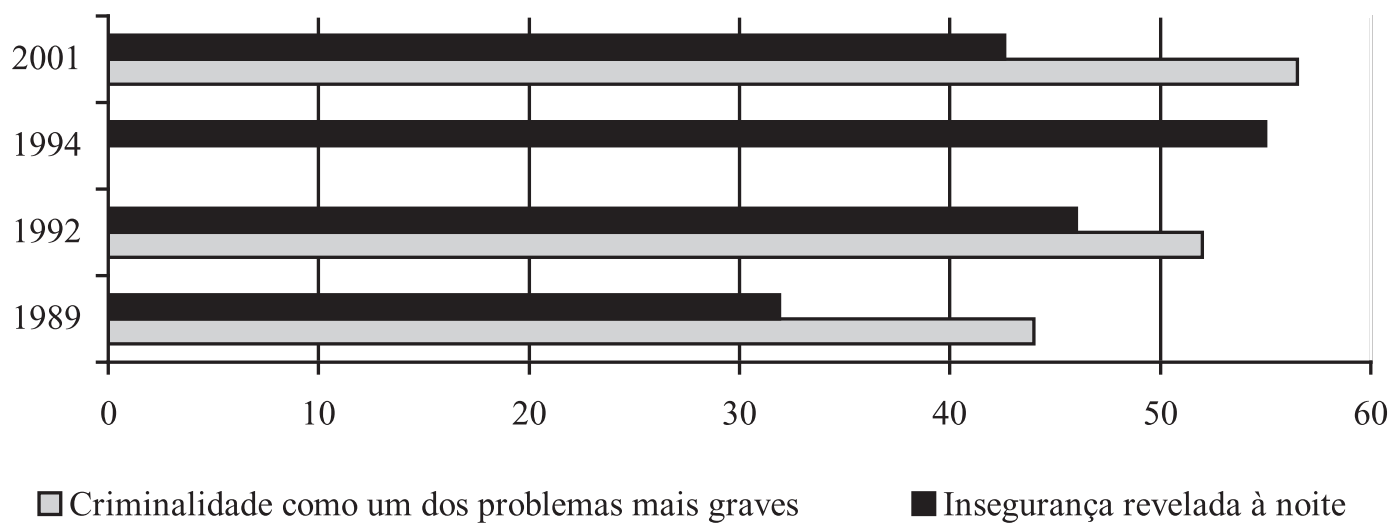

Fontes: Inquéritos de Vitimação realizados pelo Gabinete de Estudos e Planeamento do Ministério da Justiça em 1989, 1992 e 1994 , e Inquérito de Vitimação realizado pela Associação Portuguesa de Apoio à Vítima em 2001, no âmbito do Projecto Cíbele - Estudo sobre Prevenção do Crime e Vitimação Urbana.

Correlativamente, os mesmos inquéritos de vitimação começaram a revelar a existência de uma elevada insegurança, sugerindo a existência de uma relação entre esta e a preocupação com a criminalidade, ou seja, com o receio do crime. No caso da área metropolitana de Lisboa, esta relação começou a ser evidente nos anos 90, quando quase metade da respectiva população ou, pelo menos, dos actores que foram sendo inquiridos, começou a revelar, cumulativamente, uma crescente preocupação com a criminalidade e uma crescente insegurança.

A partir de meados dos anos 80 a relação entre insegurança e receio do crime deixou de poder ser dissociada, como até então havia sido, da criminalidade. Na maioria dos países europeus, os crimes contra o património, como os furtos, e alguns crimes violentos, como os roubos ou os assaltos, começaram a ser participados às autoridades policiais em números que não se verificavam pelo menos desde o fim da Segunda Guerra Mundial (Lagrange e Zauberman, 1991:247-248). Este aumento, que também se fez sentir em Portugal, embora de forma mais acentuada apenas nos anos 90 (Ferreira, 1998), obrigou a uma inversão dos discursos explicativos da insegurança urbana, dada a dificuldade em continuar a sustentar que a mesma se podia reconduzir quase exclusivamente a manipulações político ideológicas (Lagrange e Zauberman, 1991).

$\mathrm{O}$ aumento do número de actores que referiam sentir receio do crime e uma elevada insegurança relacionada com esse mesmo receio começou a evoluir, grosso modo, a par com o aumento dos crimes registados pelas autoridades policiais ou judiciais. As relações existentes entre os dois fenómenos começaram a ser impossíveis de ignorar ou de descartar como meras relações espúrias.

\footnotetext{
${ }^{4}$ Exactamente como havia acontecido ao longo de praticamente todo o século XIX e início do século XX.

${ }^{5} \mathrm{Em}$ parte porque aqueles que se sentem mais inseguros tendem, de acordo com os resultados obtidos em vários inquéritos de vitimação, a reduzir a frequência e a intensidade dos contactos com a cidade e a adoptar estratégias e medidas de protecção que os isolam cada vez mais dessa mesma cidade.
} 
No caso português, por exemplo, as autoridades policiais registaram, entre 1993 e 2000, um aumento global de 55969 crimes $(+18,2 \%)$, em que se destacam, entre outros, os crimes de furto, com mais 31362 crimes registados $(+23,6 \%)$, os crimes contra as pessoas, com mais 14376 crimes registados $(+20,9 \%)$ e os roubos, com mais 5237 crimes registados $(+43,9 \%)^{6}$. Os inquéritos de vitimação que foram sendo realizados na área metropolitana de Lisboa também começaram a revelar, não só uma elevada prevalência de crimes contra bens pessoais e familiares, na maior parte dos casos, e como era expectável, bem superior à revelada pelas estatísticas oficiais, como um aumento dessa mesma prevalência, mas sobretudo, ou apenas, nos casos dos crimes de dano e de furtos de ou em veículos (Gráfico n. ${ }^{\circ}$ 2).

Tendo como referência os dados que iam sendo disponibilizados, a maioria dos estudos então efectuados (Ferreira, 1998) confirmaram não ser possível ignorar a existência de uma relação entre receio do crime, probabilidades de vitimação e insegurança. Nesta sequência, o receio do crime começou a confirmar-se como um receio que não se podia configurar apenas como algo de irrealista ou manipulado, porque resultava de uma percepção, razoavelmente objectiva, das elevadas e crescentes probabilidades de vitimação existentes.

Gráfico n. ${ }^{\circ} 2$ - Crimes contra bens patrimoniais registados na área metropolitana de Lisboa, por 100 habitantes ou agregados familiares

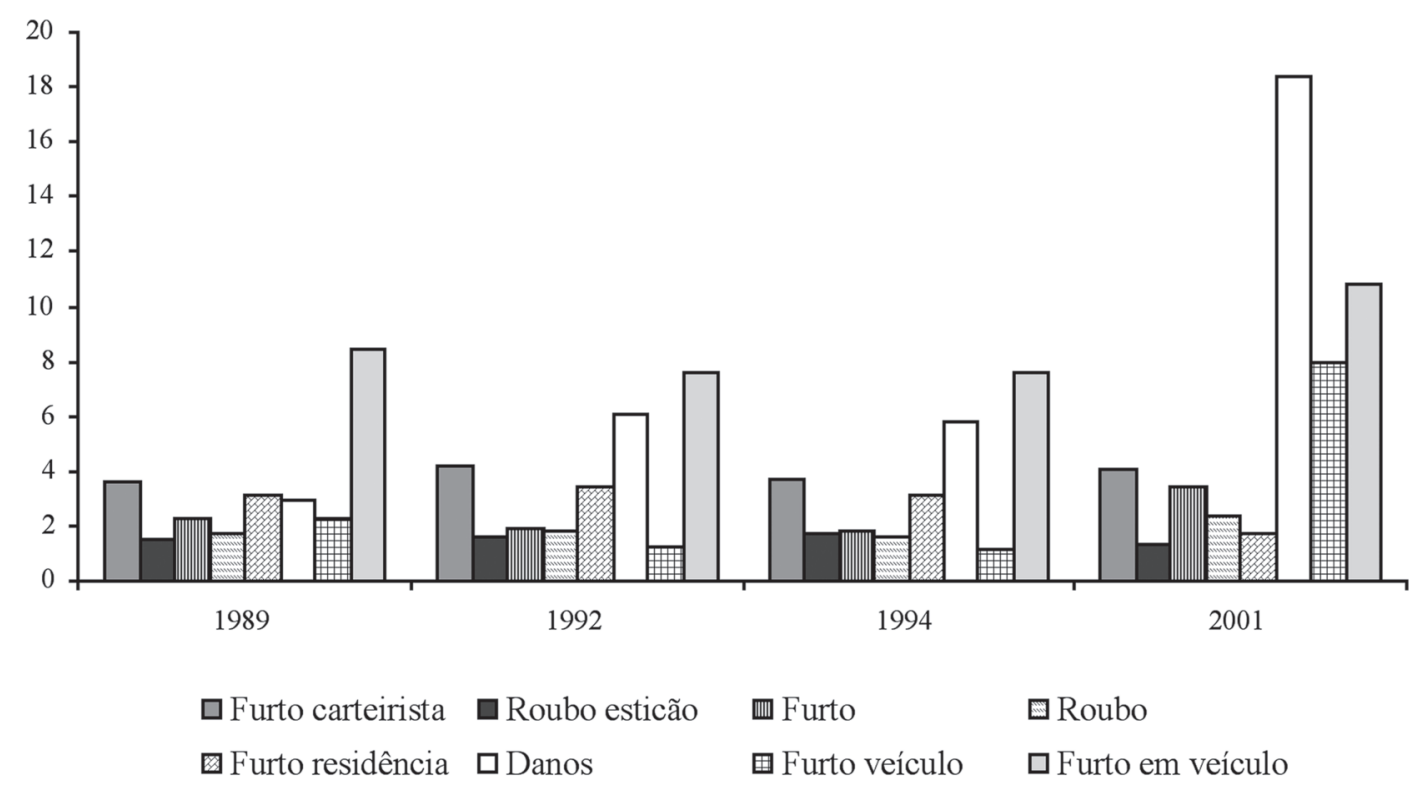

Fontes: Inquéritos de Vitimação realizados pelo Gabinete de Estudos e Planeamento do Ministério da Justiça em 1989, 1992 e 1994, e Inquérito de Vitimação realizado pela Associação Portuguesa de Apoio à Vítima em 2001, no âmbito do Projecto Cíbele - Estudo sobre Prevenção do Crime e Vitimação Urbana

Sendo o efeito das relativamente elevadas probabilidades de vitimação contra bens patrimoniais sobre a construção de uma insegurança sentida ou revelada e de novas formas de sentir e de viver a cidade compreensível e explicável, já o mesmo não se podia dizer relativamente aos crimes mais violentos. O que os dados existentes, quer aqueles relativos aos registos efectuados pelas autoridades policiais, quer aqueles obtidos através de inquéri- tos de vitimação, iam revelando era, na realidade, que a criminalidade mais violenta, em particular aquela concretizada em homicídios, tinha estabilizado ou estava a diminuir (Gráfico n. ${ }^{\circ} 3$ ). Mesmo no caso dos pequenos crimes contra a integridade física ou a honra, o que se ia constatando era que a prevalência dos mesmos era reduzida e se mantinha, apesar de algumas oscilações e de uma única excepção ${ }^{7}$, notavelmente estável (Gráfico n. $\left.{ }^{\circ} 4\right)$.

\footnotetext{
${ }^{6}$ De acordo com as Estatísticas da Justiça, compiladas e publicadas pelo antigo Gabinete de Estudos e Planeamento do Ministério da Justiça. 7 Caso das injúrias.
} 
A crescente preocupação com a criminalidade e a insegurança com ela relacionada parecia, neste sentido, estar ancorada numa contradição insolúvel. Ela estava aparentemente relacionada com uma relativa saturação de crimes, mas esses crimes eram cada vez menos violentos. Ou seja, a violência ur- bana, aparentemente geradora de elevados níveis de insegurança e de novas formas de sentir e viver a cidade, parecia reconduzir-se, na maior parte dos casos, mais a uma relativa saturação de danos patrimoniais e de incivilidades do que propriamente de crimes excepcionalmente violentos.

Gráfico n. ${ }^{\circ} 3$ - Homicídios registados em Lisboa e noutras capitais europeias, por 100000 habitantes

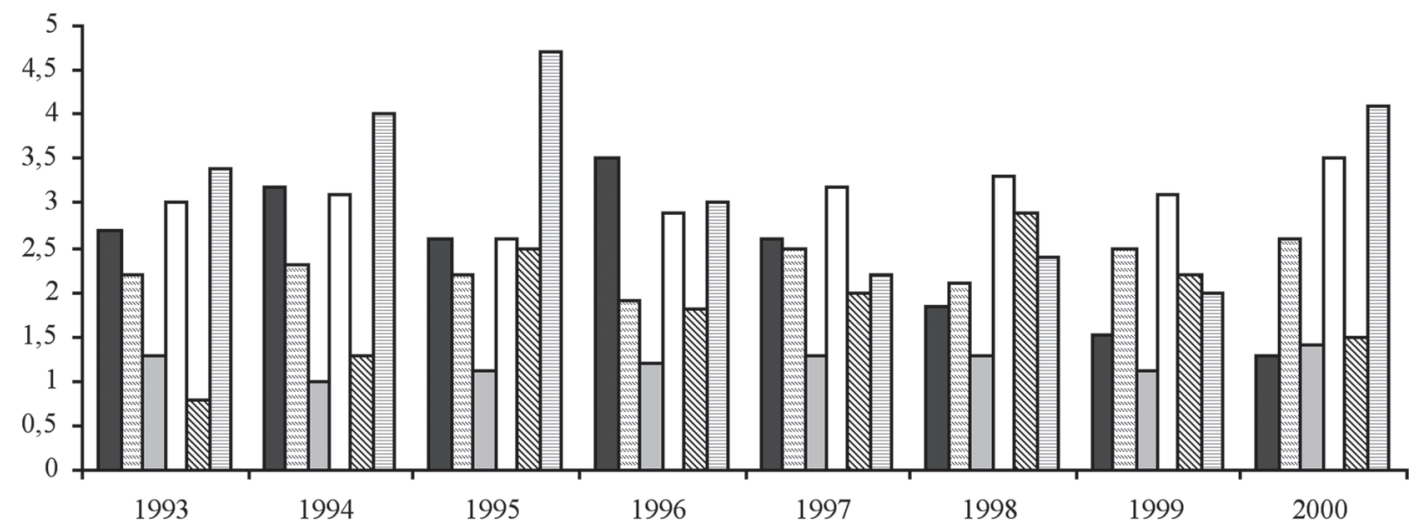

Lisboa $\square$ Londres $\square$ Roma $\square$ Madrid $\mathbb{Q}$ Dublin $\boxminus$ Paris

Fonte: U.K. Home Office, in www.homeoffice.gov.uk/rds/pdfs/400data.xls

Gráfico n. ${ }^{\circ} 4$ - Crimes contra as pessoas registados na área metropolitana de Lisboa, por 100 habitantes

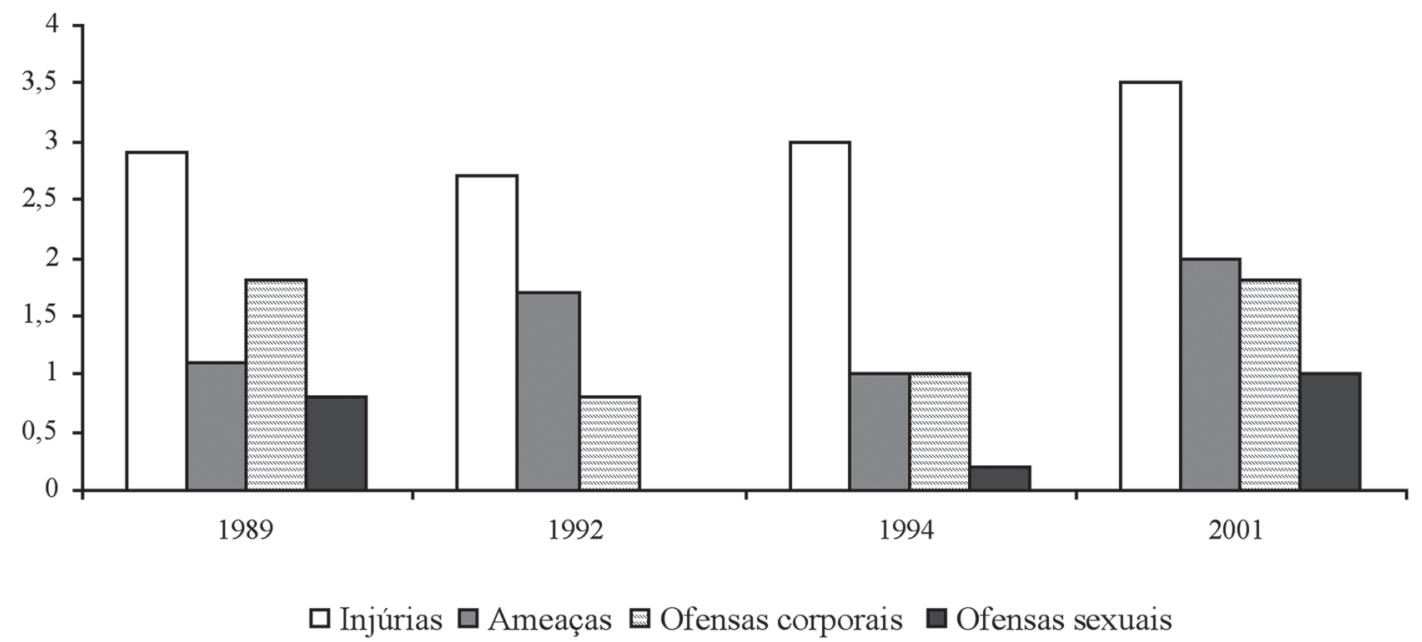

Fontes: Inquéritos de Vitimação realizados pelo Gabinete de Estudos e Planeamento do Ministério da Justiça em 1989, 1992 e 1994 , e Inquérito de Vitimação realizado pela Associação Portuguesa de Apoio à Vítima em 2001, no âmbito do Projecto Cúbele - Estudo sobre Prevenção do Crime e Vitimação Urbana. 


\section{Violência e insegurança urbana ou crise de identidade?}

A existência de uma cidade cada vez menos violenta mas cada vez mais insegura pode, numa primeira análise, ser compreendida e explicada em função do que poderemos designar por uma crise de identidade urbana. Esta identidade, que emergia quase naturalmente entre os proprietários e os não proprietários até meados do século XX, foi sendo gradualmente substituída por uma identidade mais difusa, porque construída em função de outra ordem de diferenças, em particular as existentes entre os que ameaçam e os que defendem a ordem e a estabilidade citadina. Para esta alteração terá con- tribuído o facto, como defendeu Touraine (1991: 7-13), de as diferenças sociais e económicas se terem acentuado de forma brutal nas últimas décadas do século XX. O contínuo mais ou menos gradual em que se inscreviam as diferenças entre as classes laboriosas e as classes perigosas, nos primórdios das sociedades industrializadas, foi destruído e a deu lugar a uma nova e forte clivagem, entre a classe trabalhadora e diferentes subclasses, que começaram, por efeito dos fortes movimentos imigratórios que haviam ocorrido em muitas das sociedades europeias no pós-guerra, e mais recentemente em Portugal (Gráfico n. ${ }^{\circ}$ 5), a ser constituídas, na sua maioria, por minorias, étnicas, culturais ou religiosas.

\section{Gráfico n. ${ }^{\circ} 5$ - Residentes estrangeiros (legalizados) em Portugal}

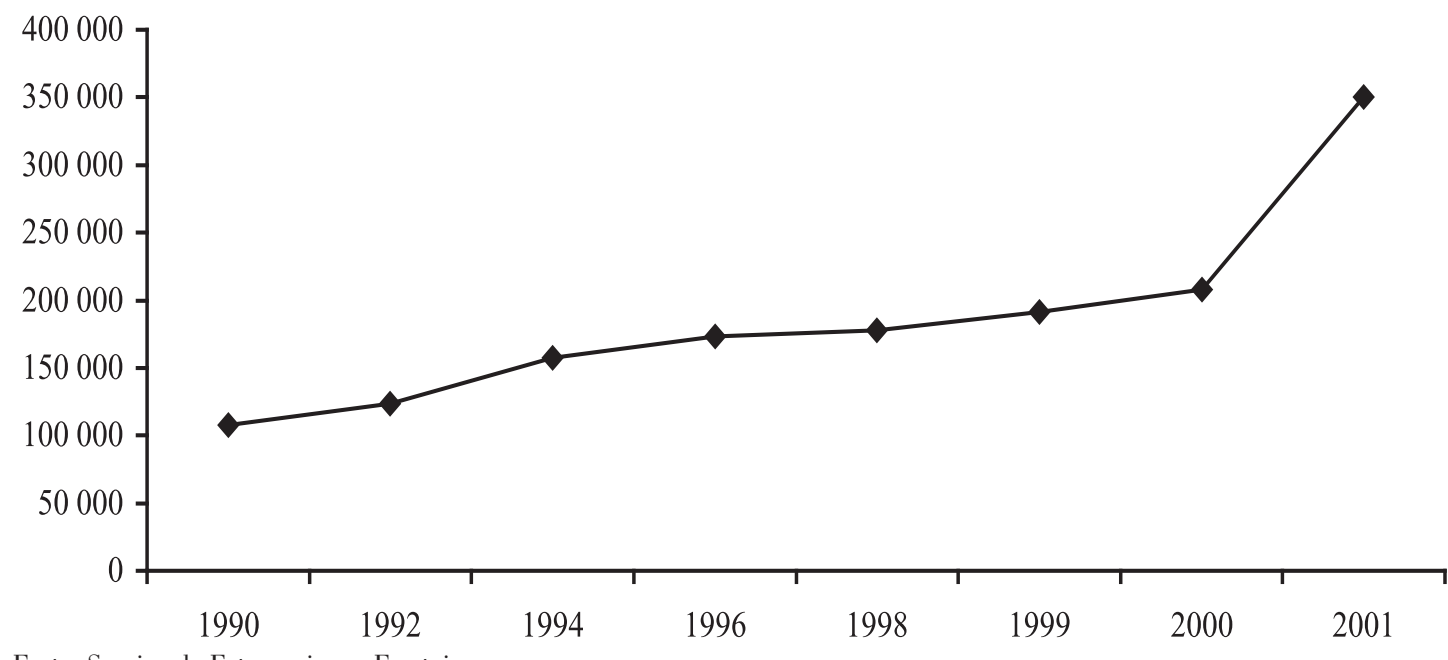

Fonte: Serviço de Estrangeiros e Fronteiras

A crise económica que se instalou a partir dos anos 70, e que apenas teve um interregno nos anos 90 , parece ter reforçado este processo de clivagem e de exclusão social, processo que fez emergir um número significativo de conflitos, étnicos e culturais, sobretudo em meios urbanos. Compreende-se, neste sentido, o motivo pelo qual, em espaços urbanos relativamente vastos e sobrepovoados, a procura de uma nova segurança identitária, por oposição a uma multiplicidade de identidades minoritárias, se tornou fulcral. Por outro lado, em sociedades que antes haviam sido caracterizadas pela abundância, e pela segurança decorrente dessa mesma abundância, em que, como salientou Ulrich Beck (1992), a energia nuclear ocupava um lugar simbolicamente central como um dos poucos riscos possíveis e prováveis, a desordem económica, social e cultural que emergiu a partir de meados dos anos 70 só poderia ter como corolário uma crescente insegurança.

Num contexto de aparente desagregação de uma identidade baseada em laços e solidariedades sociais tradicionais, a suposta violência de alguns grupos minoritários, que anteriormente era atributo do operariado e representada como legítima, ou pelo menos compreensível, face às desigualdades e injustiças sociais, começou, como o salientaram Lagrange e Zauberman (1991), a ser representada como um risco para a ordem e estabilidade social e, consequentemente, por se transformar num importante factor de insegurança. As respostas violentas accionadas por grupos estruturados em torno de identidades minoritárias deixaram, aparentemente, de ser percepcionadas em função de uma qualquer dimensão de protesto colectivo e, ao perderem a sua legitimidade expressiva, passaram ra- 
pidamente do domínio político para o domínio do direito comum. Ou seja, do direito penal.

Os responsáveis pelas novas formas de violência, algumas vezes consubstanciadas no vandalismo de bens colectivos ou privados, deixaram de ser representados como actores colectivos, dotados de uma estratégia de poder legitimada pela injustiça decorrente da dominação e da exploração do capitalismo, e passaram a ser representados como verdadeiros criminosos, cujas estratégias individuais e egoístas colocavam em causa a segurança da maioria dos actores urbanos. As formas através das quais a violência accionada por alguns actores, maioritariamente concentrados nas grandes cidades, começou a ser representada, marcou um ponto de viragem na problemática da violência urbana e da insegurança com ela relacionada, porque acabou por remeter, como era quase inevitável, para a questão da (não) integração social desses actores. Quer para a sua não integração deliberada, porque decorrente de processos conflituais de afirmação de identidades minoritárias, quer para a sua não integração originada pela recusa de todo um conjunto de valores, de atitudes ou de comportamentos representados como sendo socialmente inaceitáveis ou intoleráveis.

Neste processo, em que causas e efeitos se começaram a interligar e a influenciar de forma evidente, depressa emergiu a questão das incivilidades (Roché, 1991, e Peralva, 1997). Ou seja, das incivilidades associadas aos estilos de vida de alguns grupos minoritários, aos barulhos, aos cheiros e aos comportamentos públicos que deveriam ser privados e que, por não o serem, incomodam e perturbam o actor convencional. A questão fundamental passou a ser, não a diferença física, assunto quase tabu na modernidade, mas sim os comportamentos diferentes ou, mais especificamente, incivilizados, porque não respeitadores das normas mais básicas da vida comunitária, das minorias. Num primeiro momento parece ter sido, de facto, sobretudo a incivilidade de minorias e de estrangeiros aquilo que mais perturbou o actor cuja identidade colectiva se encontrava em crise, e não a diversidade sociocultural.

Paradigmático desta profunda alteração foi o facto de os principais conflitos sociais terem deixado de ocorrer num plano estrutural, quer no mundo económico, quer no mundo político, passando para um plano mais local, em particular o da vizinhança. Em Portugal, esta alteração foi ilustrada pelos resultados de um inquérito (Santos, 1996), que mostraram que os conflitos de vizinhança, e não os conflitos laborais ou os conflitos étnicos, tendiam a ocorrer mais frequentemente e a ser mais perturbadores para o actor convencional. Estes conflitos de vizinhança tinham, invariavelmente, a sua génese nos ruídos e nos lixos e maus cheiros, ou seja, nas incivilidades e na falta de respeito dos outros. As incivilidades, sobretudo as decorrentes dos valores, atitudes ou comportamentos públicos supostamente característicos de determinadas minorias, étnicas ou nacionais, começaram assim a emergir como um forte argumento, de natureza explicativa, da insegurança sentida ou revelada nas grandes metrópoles, num processo que, não raras vezes, mais não parecia do que camuflar uma forte xenofobia.

A lógica subjacente passou a ser linear e uniforme. Raramente nos discursos capturados se arrisca discriminar e estigmatizar as minorias ou os estrangeiros, mas apenas aqueles que não sabem respeitar as leis e as regras básicas de vivência em sociedade. Ou seja, aqueles que, pela sua falta de educação e de civilidade, começaram a colocar em causa os direitos e a segurança da maioria dos actores e que, por esse motivo, não são dignos de aceder à cidadania plena. $\mathrm{O}$ argumento da diferença de valores, de tradições e de costumes, e das incivilidades relacionadas com essa diferença, dificilmente poderia sustentar, no entanto e por si só, quer a limitação do direito à nacionalidade e à cidadania, quer a insegurança sentida ou revelada. A ameaça da diversidade identitária teve, obrigatoriamente, de se reflectir em algo de qualitativamente mais grave. Como, por exemplo, os comportamentos criminosos. A crescente associação entre crime e actores minoritários foi, como tudo o indicia, um dos fundamentos da emergência da nova preocupação com a segurança e de novas formas de sentir e de pensar a cidade.

\section{Violência das classes desfavorecidas e insegurança}

Os processos de exclusão urbana de imigrantes e outras minorias acabaram, paradoxalmente, por contribuir para despoletar fenómenos reactivos de afirmação de identidades étnicas ou culturais e, correlativamente, de novas formas de violência, já não apenas socioeconómica ou política mas, sobretudo, étnico-cultural. Estas novas formas de 
violência emergiram nos espaços mais degradados e marginalizados das grandes cidades europeias, que eram precisamente aqueles mais frequentemente representados como locais onde a delinquência se constituía como um fenómeno normal, quase um modo de vida. No entanto, a violência que aí começou a emergir dificilmente poderia ser, pelo menos num primeiro momento, encarada como mera manifestação de uma delinquência individual.

O que ressaltou, aos poucos, foi mais um conjunto de movimentos sociais, através dos quais se começaram a afirmar diferentes subculturas, invariavelmente desviantes em alguns dos seus traços mais visíveis, mas não necessariamente criminosas. Como o salientaram Lagrange e Zauberman (1991), estas subculturas desviantes emergiram e estruturaram-se muitas vezes em torno de bandos juvenis, que não se organizaram ordinariamente em torno de um projecto criminoso. Sendo inquestionável que alguns grupos ou movimentos colectivos juvenis começaram a recorrer a práticas delinquentes, por vezes manifestamente violentas, por vezes apenas simbolicamente violentas, o que se tem vindo a constatar é que não são essas práticas aquilo que melhor os caracteriza e distingue. A característica mais marcante dos grupos que tanta insegurança parecem ter começado a gerar nos actores urbanos mais convencionais parece residir mais nas diferentes formas de expressão de uma identidade colectiva alternativa do que numa violência, seja ela inata ou reactiva.

Como salientaram Lagrange e Zauberman (1991), “(...) o rap, o break dance, o movimento hip hop são reivindicações culturais que não existiam enquanto tal no início dos anos 80. Podemos falar, a seu propósito, de subcultura, não de subcultura de violência". Como podemos falar de subcultura no caso de outras expressões de uma identidade alternativa, como o são os graffities, porque se assumem como uma forma de expressão artística, invariavelmente transgressiva, mas não necessariamente criminosa ou violenta. A insegurança associada à emergência e à afirmação destas novas identidades urbanas parece ter decorrido, por isso, mais do facto de a sua dimensão social e cultural raras vezes ser conhecida e reconhecida. A representação de que os jovens, sobretudo do género masculino, oriundos de famílias e de áreas urbanas de classe baixa são, cultural e quase inevitavelmente, criminosos violentos foi, na verdade, sustentada e imposta pela sociologia americana ${ }^{8}$. Hoje sabemos que grande parte dos fundamentos teóricos e empíricos das pesquisas desenvolvidas estavam errados ${ }^{9}$, mas tal não impediu que deles tivesse emergido, não só a convicção de que grande parte dos jovens oriundos das minorias dos subúrbios são potenciais criminosos, como reacções colectivas de medo e insegurança à delinquência juvenil das classes baixas e das minorias.

Curiosamente, a maioria das análises marxistas e estruturalistas desenvolvidas posteriormente viriam a contribuir para a sustentação científica desta representação, ao procurar demonstrar a influência determinante de factores estruturais, designadamente económicos e políticos, sobre o desenvolvimento de comportamentos criminosos e, em particular, sobre a alegada, porque nesta perspectiva facilmente explicável e compreensível, maior frequência de comportamentos criminosos nas classes sociais mais baixas ${ }^{10}$. Todo o conjunto de teorizações sobre a maior prevalência de com-

\footnotetext{
${ }^{8}$ Por exemplo, Shaw, C. (1930), The Jack-Roller: A Delinquent Boy's Own Story, Chicago, Chicago University Press, Shaw, C. (1931), The Natural History of a Delinquency Career, Chicago, Chicago University Press, Shaw, C. (1938), Brothers in Crime, Chicago, University of ChicagoPress, Shaw, C. e McKay, H. (1942), Juvenile Delinquency and Urban Areas, Chicago, Chicago University Press, Cohen, A. (1955), Delinquent Boys: The Culture of the Gang, New York, The Free Press, Merton, R. (1968), Social Theory and Social Structure, Glencoe, The Free Press, Cloward, R. (1959), "Illegitimate Means, Anomie, and Deviant Behavior", American Sociological Review, 24, pp. 164-176 ou Miller, W. (1958), "Lower Class Culture as a Generating Milieu of Gang Delinquency", Journal of Social Issues, 14 (3), pp. 5-19.

9 Por exemplo, England, R. (1960), "A Theory of Middle Class Juvenile Delinquency", Journal of Criminal Law, Criminology and Police Science, Kornhauser, R. (1978), Social Sources of Delinquency, Chicago, Chicago University Press ou Bernard, T. (1984), "Control Criticisms of Strain Theories: An Assessment of Theoretical and Empirical Adequacy", Journal of Research in Crime and Delinquency, 21 (4), pp. 353-372.

${ }_{10}$ Por exemplo, Tannenbaum, F. (1938), Crime and the Community, Boston, Glinn and Company, Lemert, E., (1951), Social Pathology, New York, McGraw-Hill e Lemert, E. (1967), Human Deviance, Social Problems, and Social Control, Englewood Cliffs, Prentice Hall, Becker, H. (1963), Outsiders: Studies in the Sociology of Deviance, New York, Macmillan, Vold, G. (1958), Theoretical Criminology, New York, Oxford University Press, Quinney, R. (1969), Crime and Justice in Society, Boston, Little Brown, Turk, A. (1969), Criminality and Legal Order, Chicago, Rand McNally, Schur, E. (1971), Labeling Deviant Behavior, New York, Harper \& Row, Chambliss, W. (1974), "The State, the Law, and the Definition of Behavior as Criminal or Delinquent", in Glaser, D. (Ed.), Handbook of Criminology, Chicago, Rand McNally, pp. 7-44, Taylor, I., Walton, P. e Young, J. (1973), The New Criminology: For a Social Theory of Deviance, London, Routledge \& Kegan Paul, Chambliss, W. e Seidman, R. (1971), Law, Order and Power, Reading, Addison-Wesley, Quinney, R. (1973), "Crime Control in Capitalist Society: A Critical Philosophy of Legal Order", Issues in Criminology, 8, pp. 75-95, Quinney, R. (1974), Critique of Legal Order: Crime Control in a Capitalist Society, Boston, Little, Brown, Quinney, R. (1975), "Crime Control in Capitalist Society", in Taylor, I. et al. (Eds.), Critical Criminology, London, Routledge \& Kegan Paul e Quinney, R. (1977), Class, State, and Crime: On the Theory and Practice of Criminal Justice, New York, David McKay.
} 
portamentos criminosos entre os jovens do proletariado, acabou, paradoxalmente, por contribuir para consolidar a representação de que um dos principais riscos que ameaçam as cidades modernas reside nos comportamentos, já não apenas transgressivos nem político-ideológicos, mas essencialmente criminosos, dos membros das classes mais baixas.

Numa cidade cada vez menos violenta, a insegurança, sentida a um nível mais individual que colectivo e tendo como objecto privilegiado, não as desigualdades e as injustiças socioeconómicas, mas a ameaça colocada pelas classes marginais ${ }^{11}$ pode, neste sentido, ser entendida como um dos resultados da interligação e interacção entre os diferentes factores que contribuíram para a selecção dos crimes cometidos pelas classes baixas ou, mais genericamente, pelas minorias, como um dos principais factores de insegurança. A persistente dificuldade em destrinçar entre práticas de procura e de afirmação de uma identidade colectiva, mesmo que transgressiva ou quase delinquente, e comportamentos criminosos, invariavelmente violentos, foi instrumental para a sustentação de todo um conjunto de medos e de inseguranças que, não raras vezes, iludiram, e ainda iludem, a verdadeira realidade dos espaços urbanos que são qualificados como perigosos.

Salientamos, no entanto, que se todo este conjunto de teorizações encontrou, e ainda encontra, tão elevado eco na opinião pública é porque uma maior dificuldade em lidar com uma elevada heterogeneidade identitária está invariavelmente relacionada com um maior receio do crime e uma maior insegurança. Pesquisas com a realizada por Lane e Meeker (2000: 497-521) revelaram, a este propósito, a existência de uma relação quase directa e linear entre preocupações com a diversidade étnica, e com os gangs associados a determinadas etnias, e o receio do crime. A intensidade dos preconceitos étnicos parece, por sua vez, depender da conjugação de uma multiplicidade de factores (Katz e Hass, 1988: 893-905). Uma pesquisa efectuada por Palmer (1996) revelou, por exemplo, que os actores mais directamente afectados por fenómenos como o desemprego ou a criminalidade, ou residentes em áreas mais marcadas por estes fenómenos, tendem a revelar maior dificuldade em lidar com as diferenças identitárias e a opor-se mais veementemente a todo o tipo de processos, como a imigração, que possam contribuir para acentuar essas diferenças. Este mesmo tipo de actores tende, ainda, a estimular ou a envolver-se em estratégias relativamente violentas de redução dos riscos de vitimação, ou seja, em movimentos sociais mais ou menos radicais e xenófobos.

\section{Espaços Perigosos e Insegurança}

A compreensão da paradoxal relação que está subjacente à maior insegurança sentida ou revelada em cidades cada vez menos violentas não pode ignorar que uma relativa saturação de incivilidades, de pequenos furtos e de actos de vandalismo, mais do que crimes excepcionalmente violentos, está a ocorrer num contexto de forte pulverização e incomunicabilidade identitária. Esta incomunicabilidade parece explicar, por sua vez, todo um conjunto de representações sobre a perigosidade de determinados espaços urbanos e dos seus residentes ou frequentadores. As relações que têm sido encontradas entre as representações que são accionadas sobre espaços urbanos de elevado risco e, por isso, perigosos, e maiores ou menores níveis de insegurança têm mostrado, em particular, que a avaliação e a selecção do crime violento como risco primordial se insere num plano em que por vezes intervém mais uma incomunicabilidade identitária que propriamente elementos racionais e lógicos.

Os sentimentos de insegurança aparecem sistematicamente associados a uma percepção de baixo domínio e de controlo de alguns espaços e esta percepção parece ser, por sua vez, influenciada, quer pelas características dos respectivos habitantes, quer pelas características arquitectónicas de edifícios, ruas e outros espaços públicos. A maioria das pesquisas realizadas nos Estados Unidos tem revelado que os espaços representados como sendo mais perigosos são aqueles habitados ou frequentados por actores estranhos (Cf. por exemplo, Warr, 1990), enquanto que as pesquisas realizadas em França têm revelado que os espaços representados como mais perigosos são constituídos por locais habitados ou frequentados por imigrantes ou actores pertencentes a minorias étnicas (Rico e

\footnotetext{
${ }^{1}$ Ou seja, classes muito semelhantes às classes perigosas que, ao longo do século XIX, haviam contribuído para legitimar o monopólio da violência legítima conquistado pelos Estados modernos.
} 
Salas, 1988). Ou seja, por actores possuidores de características identitárias quase totalmente dissemelhantes às da maioria da população e, por isso, potencialmente ameaçadoras porque sistematicamente associadas à delinquência juvenil e ao crime violento. Os bairros degradados, ou de habitação social, constituem, a este nível e como salientou Fernandes (1994:11-27), referências incontornáveis, porque são invariavelmente representados como lugares onde se geram todos os criminosos e todos os riscos e inseguranças daí deri$\operatorname{vadas}^{12}$.

Mas não são apenas as características identitárias dos habitantes ou frequentadores de determinados espaços urbanos aquilo que parece contribuir para a construção das representações que os qualificam como perigosos. As próprias características arquitectónicas também parecem contribuir, de forma acentuada, para a diminuição dos sentimentos de domínio e de controlo sobre alguns espaços urbanos e, consequentemente, para a consolidação das representações sobre a sua perigosidade. A existência de recantos mal frequentados, de ruas ou praças mal iluminadas, de habitações ou estabelecimentos degradados ou sujos, tem sido, por exemplo, frequentemente referenciada como geradora de maiores receios de vitimação e de insegurança (Bannister, 1993: 69-83). O que parece estar subjacente, neste caso, é que as características físicas de determinados espaços contribuem para a redução dos níveis de controlo sobre os riscos existentes. As relações que são estabelecidas, relativamente aos espaços urbanos desconhecidos e perigosos, entre as suas características identitárias e físicas tendem, neste sentido, a gerar uma espécie de poderosa topografia do receio (Fernandes, 1994) que, podendo ser tributária de uma saturação de incivilidades e de crimes, é também relativamente independente das probabilidades reais de vitimação.

Estas representações colectivas parecem, assim, conjugar duas dimensões fundamentais. Por um lado aquela que decorre da não familiaridade com um elevado número de espaços urbanos mais ou menos periféricos, e marginais, às dinâmicas socioeconómicas e funcionais convencionais das grandes cidades. Por outro lado, a dimensão que decorre, quer do desconhecimento associado a essa não familiaridade, quer da persistente concepção de que alguns espaços urbanos são perigosos, porque são habitados, controlados e dominados por criminosos enquadrados em gangs, mais ou menos organizados e violentos. Gangs que, por sua vez, transportam, não raras vezes, a sua violência para o resto da cidade sempre que podem ou lhes permitem, confirmando, desta forma, a objectividade e a justeza das representações que são accionadas sobre os seus espaços de origem.

Os espaços colectivamente representados como perigosos tendem, assim, a ser evitados e, porque são evitados e porque neles se desinveste afectiva e materialmente, num processo em que o desejo de que não existissem parece ser dominante, tendem a fechar-se progressivamente sobre si mesmos, tornando-se também menos conhecidos, mais hostis e mais geradores de receio, num ciclo vicioso de incomunicabilidade social e de insegurança derivada dessa incomunicabilidade. $\mathrm{O}$ desejo de fazer desaparecer os espaços de perigo e de medo tem, por isso e aparentemente, decorrido mais do receio do crime, e da insegurança que ele gera, do que propriamente da vontade de reduzir, através de projectos potenciadores da inclusão socioeconómica, cultural e política dos seus habitantes, a sua pobreza, degradação e miséria desumana.

\section{A Cidade Violenta dos Meios de Comunicação Social}

Um terceiro factor que pode contribuir para a compreensão da relativa dissociação entre violência e insegurança reside no facto de a matriz de conhecimentos disponíveis sobre a realidade criminal ser em parte estruturada em função da realidade que é construída e transmitida pelos diferentes meios de comunicação social. Estes e, em particular, a televisão, constituem hoje, como é unanimemente reconhecido, um poderoso instrumento de difusão de valores e de atitudes junto de actores e de classes sociais que não se esgotam, nem muitas vezes se afiliam, em comunidades que possam exercer uma função confirmatória, ou contextualizadora, do que é veiculado pelos meios de comunicação social. A dependência, de um número mais ou menos vasto de actores, da informação, e dos valores e atitudes, que são veiculados pelos meios de comunicação social pode explicar, como tem sido

12 Designados, de forma exemplarmente ilustrativa, de “îlots d'insécurité" por Rémy e Voyé (1981). 
defendido, os crescentes níveis de receio do crime, e de insegurança. A insegurança revelada, numa cidade cada vez menos violenta, seria, nesta perspectiva, indissociável das histórias que os meios de comunicação social contam sobre a violência existente, sobre os criminosos, sobre as vítimas e sobre os contextos e as circunstâncias em que ocorrem os crimes mais violentos (Monteiro, 1999: 321-339).

As abordagens mais deterministas têm defendido que actores que sejam espectadores assíduos da televisão, ou ouvintes ou leitores de outros meios de comunicação social, tendem a alterar a percepção que têm da realidade social em que estão inseridos, podendo confundi-la com a realidade ficcional (Cf. Gerbner, 1972 e Gerbner e Gross, 1976) que é caracterizada, na maioria dos casos, por um quotidiano de crime e de violência (Milavsky, 1982). Da alteração induzida pelos meios de comunicação social tenderia a resultar, por exemplo, aquilo que Wober (1978: 315-321) descreveu como uma percepção paranóide do mundo, ou que Signorielli (1990) descreveu como uma síndroma do mundo mau. Estas percepções distorcidas da realidade tenderiam, por sua vez, a alterar os diferentes tipos de interacção com os outros, a induzir medidas desproporcionadas de defesa contra o crime e, estas, um maior isolamento e uma maior insegurança. Neste sentido, os meios de comunicação social tenderiam a constituir-se, em simultâneo, como uma causa e como um efeito do receio do crime e da insegurança.

No entanto, as pesquisas empíricas que têm sido realizadas sobre os efeitos da exposição à realidade ficcional dos meios de comunicação social são, não apenas escassas, como produziram resultados pouco consistentes, porque muitas vezes contraditórios (Monteiro, 1999). Uma mais elevada exposição a notícias televisivas ou radiofónicas relativas a eventos criminais tem surgido com podendo estar significativamente associada a níveis, também eles mais elevados, de receio do crime, mas a mesma relação parece já não ser tão evidente nem linear quando se trata de eventos criminais descritos, com bastante detalhe, em jornais ou em revistas. Nestes casos, tem-se constatado que os efeitos, em termos de receio do crime, da exposição à realidade criminal que é descrita nos diferentes tipos de meios de comunicação social escrita tendem a ser mediados por um significativo número de outros factores, entre os quais se destaca o efei- to confirmatório, ou não, de fontes de informação aparentemente mais credíveis, como os familiares ou a vizinhança (Williams e Dickinson, 1993, 33-56).

Para além das diferenças derivadas das próprias características dos meios de comunicação social, e da forma como os eventos criminais neles são relatados, este tipo de relação ainda parece ser fortemente influenciada por variáveis como a idade, o género ou a classe social de pertença. $\mathrm{Ou}$ seja, tudo indicia que os efeitos da exposição aos meios de comunicação social tendem a variar em função de múltiplos outros factores, entre os quais se tem destacado a maior ou menor afinidade socioeconómica, demográfica ou identitária com as vítimas dos eventos criminais mais frequentemente relatados (Rico e Salas, 1988). Esta afinidade pode contribuir para explicar, por exemplo, a aparente relação existente entre o elevado número de notícias relativas a vitimações, invariavelmente violentas, de mulheres, e os maiores níveis de receio do crime que as mulheres, em geral, revelam na maioria dos estudos até agora efectuados (Cf. Chiricos, T. et al., 1997 e Winkel e Vrij, 1990).

A relativa ausência de relações consistentes entre a exposição à realidade criminal tornada acessível pelos meios de comunicação social e a insegurança parece poder ser explicada por duas ordens de factores. Em primeiro lugar, tudo indicia que a maioria dos actores reconhece que os eventos criminais que mais são relatados nos meios de comunicação social não são os mais frequentes, nem os mais representativos da realidade criminal, mas antes os que maior probabilidade apresentam de atrair as atenções e, consequentemente, de garantir maiores audiências. Em segundo lugar, a maioria dos actores também parece ignorar muitos desses mesmos relatos, na medida em que os mesmos tendem a situar a criminalidade numa esfera afastada da sua comunidade e da sua vida quotidiana e, por isso, pouco provável e pouco relevante em termos de riscos e da necessidade de adopção de estratégias de redução desses riscos (Tyler, 1984: 27-38).

A distorção ou, numa perspectiva mais radical, a manipulação que é operada pelos meios de comunicação social tem, apesar de tudo, sido confirmada por inúmeras pesquisas. Uma delas revelou, por exemplo, que a maioria dos eventos criminais relatados na imprensa escrita da Grã-Bretanha (Mawby e Brown, 1984: 82-94) dizem respeito a 
homicídios e a roubos que envolvem, sobretudo, vítimas jovens, do género feminino e pertencentes à classe social média e média alta. $\mathrm{O}$ problema é que este tipo de eventos, e de vítimas, representam, de acordo com as estatísticas policiais e judiciais disponíveis, apenas uma pequena parte da verdadeira realidade criminal. Esta distorção, ou evidente manipulação, da realidade criminal pode, neste sentido e por exemplo, explicar parte dos mais elevados níveis de receio do crime e de insegurança que são revelados pelas mulheres na maior parte das sociedades ocidentais.

A distorção da realidade criminal operada pelos meios de comunicação social também parece ser frequente quando estão em causa as características dos agressores. Não raras vezes (Welch, 2002: 3-30), os eventos criminais mais frequentemente relatados, e aos quais é dada maior cobertura e destaque, são aqueles em que os criminosos mais correspondem a estereótipos clássicos, como, por exemplo, jovens do género masculino pertencentes a minorias étnicas. Pelo contrário, os eventos que envolvem criminosos oriundos da classe média parecem ser frequentemente ignorados ou, pelo menos, minimizados em termos de destaque e de espaço ocupado (Baer e Chambliss 1997: 87-107).

Até que ponto a distorção que é operada pelos meios de comunicação social, que visa mais o entretenimento do que a informação, tende a contribuir, ou não, para significativas alterações da forma como a realidade criminal é percepcionada e sentida continua, no entanto, a constituir-se como uma questão carente de maior sustentabilidade empírica. Os únicos dados consistentes apenas indiciam que uma maior exposição aos diferentes meios de comunicação social não produz efeitos directos e lineares sobre os níveis de receio do crime e de insegurança. Algumas pesquisas (Williams e Dickinson, 1993) encontraram mesmo aquilo que parece ser um efeito bidireccional, na medida em que os actores que mais procuram notícias sobre crimes tendem a ser aqueles que, à partida, revelam níveis mais elevados de receio do crime. Neste sentido, todos os resultados até agora obtidos apontam para uma relação não directa nem linear, que parece ser ainda influenciada por experiências directas ou indirectas de vitimação e por outras fontes de informação, como os vizinhos, amigos ou familiares. Talvez seja por este motivo que, como já o havia salientado Roché (1991), se tem revelado quase sempre improdutivo fazer da opinião pública, tal como a mesma se estrutura e se transmite nos meios de comunicação social, uma das mais importantes variáveis a explicar, ou variáveis explicativas, do receio do crime e da insegurança urbana.

\section{Violência e Insegurança, ou Descon- fiança no Sistema de Justiça?}

Um quarto e talvez mais importante factor explicativo para a crescente insegurança sentida ou revelada parece residir nas representações existentes sobre a ineficácia do sistema de justiça penal. Este tipo de representações parece traduzir-se, entre outras consequências, em maiores níveis de receio do crime e de insegurança, no crescente recurso a estratégias de autoprotecção e, mais recentemente, no recurso a organizações não governamentais de segurança (Esteves, 1999). O tipo, a intensidade e a qualidade das respostas, reais ou representadas, que são accionadas pelo sistema de justiça penal parecem estar relacionadas com níveis mais elevados de receio do crime e de insegurança, sobretudo em contextos de elevada saturação criminal e esta relação parece decorrer do facto de o sistema de justiça penal ser representado, por uma elevada percentagem de actores, como incapaz de assegurar um eficaz combate ao crime. A antecipação da incapacidade ou do desinteresse das autoridades policiais, bem como a antecipação da morosidade e do custo de qualquer procedimento criminal, têm sido, por exemplo, frequentemente identificadas como um dos principais motivos que levam um elevado número de vítimas, quase seis em cada dez no caso da área metropolitana de Lisboa (Gráfico n. ${ }^{\circ}$ 6), a não participar os crimes de que são alvo. 
Gráfico n. ${ }^{\circ} 6$ - Crimes participados (em \% do total de crimes ocorridos) às autoridades policiais ou judiciais e insatisfação com estas autoridades (em \% das vítimas que participaram) na área metropolitana de Lisboa.

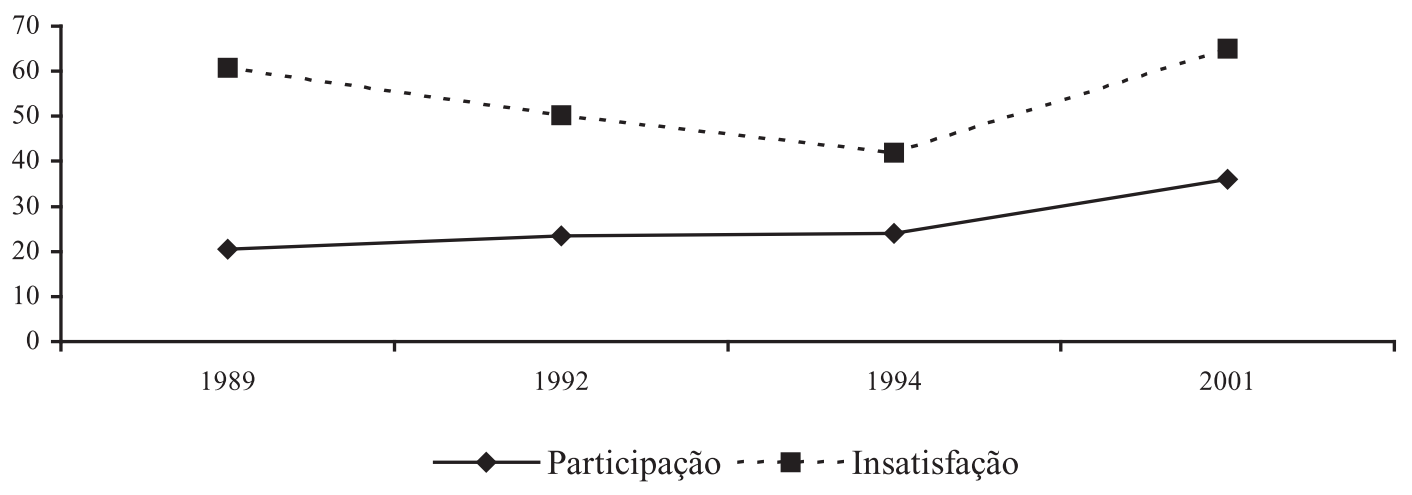

Fontes: Inquéritos de Vitimação realizados pelo Gabinete de Estudos e Planeamento do Ministério da Justiça em 1989, 1992 e 1994, e Inquérito de Vitimação realizado pela Associação Portuguesa de Apoio à Vítima em 2001, no âmbito do Projecto Cíbele - Estudo sobre Prevenção do Crime e Vitimação Urbana.

Para além da representação, que aparentemente se encontra em regressão, sobre a relativa incapacidade de resposta da polícia ou do sistema de justiça, tem-se ainda vindo a constatar a existência de elevados índices de insatisfação nas, poucas, vítimas de crimes que optam pela participação. No caso particular da área metropolitana de Lisboa, quase metade das mesmas tem admitido ter ficado pouco satisfeita ou nada satisfeita, nomeadamente por as autoridades policiais ou judiciárias se terem revelado pouco interessadas, por não terem apanhado os autores dos crimes, por não terem recuperado nenhum bem, por não terem dado ou demorado muito a dar informações, por terem sido pouco delicadas ou desagradáveis ou ainda por não terem comparecido ou terem demorado muito a responder ao pedido de auxílio.

Estes elevados índices de insatisfação, que parecem ser comuns, embora nem sempre de forma tão acentuada, à maioria das sociedades ocidentais (Rico e Salas, 1988), parecem, ainda, constituir um reflexo do próprio desenvolvimento processual da maioria dos crimes que são anualmente participados às autoridades policiais. No caso português (Almeida e Alão, 1995: 97), mais de metade das participações efectuadas em 1994 foram arquivadas, cerca de uma em cada três tinha dado origem a um processo-crime, que ainda seguia a respectiva tramitação processual em 1995, enquanto que apenas $5 \%$ das mesmas tinham resultado num julgamento.

O conjunto de representações sobre a ineficácia das autoridades policiais e judiciárias, bem como os elevados níveis de insatisfação relativamente à organização e ao funcionamento da polícia e do sistema de justiça penal, têm vindo a ser referenciados como podendo explicar parte dos elevados níveis de receio do crime e de insegurança existentes (Rico e Salas, 1988), em parte porque coincidiram, historicamente, com o desaparecimento, ou com uma crescente ineficácia, de uma multiplicidade de mecanismos comunitários de controlo do crime e, correlativamente, com uma crescente dependência, sobretudo em comunidades urbanas, de organizações formais e especializadas de prevenção e de repressão do crime. O próprio aparecimento das organizações policiais, tal como as conhecemos hoje, coincidiu, historicamente, e como o salientaram Dias e Andrade (1984), com o das modernas sociedades industrializadas e urbanizadas, constituindo-se como estruturas burocráticas e profissionalizadas que, para todos os efeitos, substituíram, pela força e graças ao monopólio da violência legítima conquistado pelos Estados modernos, os mecanismos informais de controlo social que operavam a um nível comunitário.

A crescente dependência do sistema formal de justiça penal, que não pode ser dissociada da transferência para o Estado desse monopólio da violência, parece ter produzido, no entanto, um efeito paradoxal. É que, como também o salientaram Dias e Andrade (1984), embora as organizações formais e especializadas de prevenção e de repressão do crime, em que se destacam as polícias, o ministério público, os tribunais e os serviços 
prisionais, se tenham profissionalizado e burocratizado de forma muito acentuada nas últimas décadas, não parecem ter conseguido resistir à avalanche resultante da massificação do direito à regulação formal de inúmeros conflitos sociais e interpessoais. E, não menos importante, do direito universal à protecção e à segurança contra o crime e os criminosos.

Os dados relativos à realidade portuguesa mostram, por exemplo, que nas últimas décadas do século XX o número de processos entrados nos tribunais judiciais portugueses passou de 318677 , em 1974, para 727952 , em 2000 ${ }^{13}$. O número de magistrados judiciais também aumentou muito significativamente, passando de 292, em 1974, para 1624, em 2000, bem como o número de magistrados do ministério público, de 441 para 1180, e o número de outros funcionários judiciais, de 2695 para 9040. Este significativo aumento de magistrados e de funcionários não impediu, no entanto, que o número de processos, quer penais, quer cíveis ou laborais, se fosse acumulando nos tribunais. Exemplo disso é o facto de, em 1985, poucos processos penais serem resolvidos num período inferior a doze meses, considerando a data de ocorrência do crime e uma decisão judicial final, em primeira instância. Este período de tempo aumentou mesmo, em 2000, para 17 meses. As estatísticas da justiça portuguesas mostram ainda que, nos últimos anos, o número de ocorrências anualmente participadas às autoridades policiais e judiciais passou de cerca de 223000 , em 1985, para 363 297, em 2000. Ou seja, registou-se um aumento de mais de 140000 ocorrências anuais no espaço de apenas dezasseis anos ${ }^{14}$. Para este aumento terão contribuído, sobretudo, os pequenos crimes contra bens patrimoniais, nomeadamente os furtos, num processo que, de resto, parece ter ocorrido, em termos de volume e de evolução, em praticamente todas as sociedades ocidentais (Lagrange e Zauberman, 1991).

A crescente procura do sistema de justiça penal parece ter sido motivada por um complexo conjunto de factores, em que o aumento real da criminalidade talvez não tenha sido o mais decisivo.
O que parece ter ocorrido não foi apenas, como o salientaram autores como Cusson (1983), um crescimento, sem precedentes nas sociedades ocidentais e, em particular, europeias, de bens patrimoniais com um elevado valor material e simbólico e facilmente furtáveis e transaccionáveis nos mercados paralelos. Ou seja, um aumento das oportunidades criminais existentes que se teria traduzido, quase directamente, num volume, nunca antes verificado, de furtos e de roubos. Para este aumento terão contribuído, também, alterações qualitativas ao nível da própria necessidade de participação.

A generalização de seguros, que cobrem roubos, furtos ou danos que têm como alvo residências, veículos automóveis e uma multiplicidade de outros bens patrimoniais, a generalização do uso de cheques e de cartões bancários e a generalização de documentos de identificação, sem os quais se torna virtualmente impossível sobreviver no dia-a-dia, parecem também ter contribuído, de forma decisiva, para o crescimento de participações, motivadas assim por constrangimentos de ordem legal ou administrativa e que, na ausência desses mesmos constrangimentos, provavelmente nunca seriam antes formalizadas. Acresce, ainda, o facto de, aparentemente, a resolução de um significativo número de conflitos interpessoais, familiares, de vizinhança, de trabalho ou derivados de dívidas, quer a instituições, quer a particulares, ter começado a ser formal e legalmente regulada ou a exigir o recurso à mediação do sistema de justiça. Exemplo disso é, mais uma vez no caso português, a evolução que tem ocorrido ao nível da participação, às autoridades policiais, de ofensas simples à integridade física ou de difamações, calúnias ou injúrias que passam, apenas entre 1993 e 2000, de 38 184 participações anuais para $47557^{15}$.

$\mathrm{O}$ recurso à participação formal a uma autoridade judicial, que durante muito tempo se constituiu como um procedimento absolutamente excepcional para a esmagadora maioria dos actores, parece ter-se transformado, aos poucos, num procedimento, também ele absolutamente normal, de resolução de uma multiplicidade de conflitos e de ocorrências criminais. Na sequência do que até aqui

\footnotetext{
${ }^{13}$ De acordo com as já referidas Estatísticas da Justiça, compiladas e publicadas pelo antigo Gabinete de Estudos e Planeamento do Ministério da Justiça.

14 Idem.

15 De acordo com as já referidas Estatísticas da Justiça.
} 
foi explanado, este efeito era praticamente inevitável e acabaria, quase só por si, por contribuir para o estrangulamento e para o bloqueio do sistema de justiça penal. Exemplo disso foi a redução drástica das taxas de esclarecimento das ocorrências participadas às autoridades policiais, em particular as dos furtos (Lagrange e Zauberman, 1991), que constituem a esmagadora maioria dessas mesmas ocorrências. Os tempos de instrução e de julgamento dos milhares de processos acabaram também por aumentar de forma muito significativa e, não menos importante, as próprias taxas de condenação acabaram por diminuir ${ }^{16}$.

A divulgação de todo este conjunto de indicadores de relativa ineficácia das autoridades policiais e judiciais, e dos tribunais, não poderia deixar de começar a ser representada, pelos actores em geral, como uma confirmação da quase total incapacidade do Estado para garantir a protecção e a segurança dos corpos e dos bens patrimoniais da maioria dos seus cidadãos ${ }^{17}$. O problema, neste caso, é que os Estados modernos haviam garantido parte da sua legitimidade precisamente em função dessa capacidade. Como estas representações se acentuaram num momento em que a maioria dos actores se havia habituado a ver no Estado o principal recurso para a resolução de todos os seus problemas, criminais ou não, e em que a maioria das comunidades, sobretudo as urbanas se viu incapaz, senão mesmo formalmente impedida, de assegurar alguma forma de protecção e de segurança de pessoas e de bens, compreende-se o motivo pelo qual as mesmas começaram a surgir sistematicamente relacionadas com níveis mais elevados de receio do crime e de insegurança.

Esta relação carece, ainda, de ser inserida num contexto mais geral, em que não releva apenas o aumento, em quase todos os países europeus, das ocorrências criminais que são anualmente participadas. Ou seja, uma relativa saturação de incivilidades e de crimes. Este aumento foi, como o referiu Roché (1991:14), “(...) acompanhado pela urbanização, pelo crescimento económico que permite adquirir bens de consumo (...) como nunca antes tinha ocorrido na história e pela modificação dos estilos de vida e, mais acentuadamente, dos valores. Este ponto de vista geral é importante, mesmo que delicado, porque sabemos como o sentimento de insegurança não se apoia apenas sobre o crime para se exprimir, fazendo também apelo às mutações da organização social". O problema é que estas profundas mutações ocorreram em simultâneo com uma incapacidade dos sistemas de justiça penal “(...) para responder à multiplicação de delitos (e ainda mais dos actos de incivilidade pouco relevantes para o direito, mas essenciais para os protagonistas) através de penas apropriadas, provocando a sobrelotação das prisões e tentativas caóticas do Estado para responder" (Roché, 1991:14) às solicitações que lhe são efectuadas.

A representação sobre a ineficácia do sistema de justiça penal para investigar e julgar todo um conjunto de incivilidades e de pequenos e grandes crimes e, consequentemente, para assegurar a protecção e a segurança das pessoas e dos bens, parece ainda ter sido reforçada pela representação de que, à ineficácia do sistema de justiça para prevenir, investigar e julgar, se tem vindo a juntar uma quase total incapacidade para punir exemplarmente os criminosos. Esta representação, que parece ter na sua base uma profunda desconfiança relativamente à forma como o próprio sistema de justiça está estruturado e funciona, tem vindo a ser detectada na maioria das sociedades ocidentais (Lagrange e Zauberman, 1991). No caso português, um estudo realizado em 1996 (Santos, 1996) revelou, por exemplo, que cerca de $71 \%$ dos inquiridos estavam convictos de que um culpado pela prática de um delito não seria necessariamente condenado em tribunal.

Esta representação tornou-se particularmente delicada a partir do momento em que voltaram a reemergir duas questões problemáticas: a da delinquência juvenil e, em parte a ela associada, a convicção de que a maioria dos criminosos não é detectada, nem julgada, nem eficazmente punida pelo sistema formal de justiça penal. No caso da delinquência juvenil, o direito, que havia sido conquistado no início do século $\mathrm{XX}^{18}$, de não penalização exemplar, nomeadamente através de castigos corporais ou de pena de prisão, de todo e qualquer acto delituoso cometido por um menor,

\footnotetext{
${ }^{16}$ Que, no caso português, terá atingido um dos mínimos históricos em 1991, ano em que apenas foram condenados $32 \%$ dos arguidos, de acordo com as já citadas Estatísticas da Justiça.

17 Como também o referiu Robert, P. (1990).

${ }^{18}$ No caso português, a Lei de Protecção à Infância de 27 de Maio de 1911 subtraiu os menores de 16 anos à tutela penal, e à prisão. Em França, os menores de 13 anos foram excluídos da tutela penal em 1912, o mesmo tendo ocorrido em 1920 em Espanha e em 1922 e 1923 na Alemanha.
} 
começou recentemente a ser representado como um direito insustentável e intolerável, na medida em que a maioria das incivilidades, dos danos, dos furtos, dos roubos ou das agressões, estaria, precisamente, a ser cometida por menores ${ }^{19}$. Ignorando, em larga medida, a constatação, cientificamente sustentada, de que todo e qualquer jovem só é cognitivamente capaz de efectuar uma avaliação objectiva e consciente de todas as possíveis consequências de um suposto acto ilícito a partir dos catorze ou dezasseis anos, depressa se generalizou a convicção de que muitos menores, por saberem não poderem ser detidos nem condenados a uma pena de prisão, estariam a aproveitar deliberadamente este direito para cometer uma série infindável de crimes e, consequentemente, a gerar elevados níveis de receio e de insegurança na sociedade.

Embora dificilmente sustentável, esta representação, bem com a de que os menores deveriam voltar a ser sujeitos a medidas punitivas mais duras e eficazes, tem-se generalizado em sociedades em que a população apresenta níveis etários cada vez mais elevados e em que a maior parte dos comportamentos criminosos são percepcionados como sendo cometidos por gangs de jovens pertencentes a minorias problemáticas. Num contexto em que se conjugam factores etários e identitários, uma vez que os jovens pertencentes a minorias identitárias começam a constituir uma significativa percentagem de todos os jovens, por efeito do significativo envelhecimento da população de acolhimento, a representação de que os menores têm de ser punidos exemplarmente tem dado origem a todo um conjunto de respostas, ainda não penais, que vão da responsabilização, penal ou cível, dos pais, passando por programas de recolher obrigatório de menores à noite, de inculcação de boas maneiras e de uma maior civilidade nas escolas, e mesmo de criação de unidades policiais especializadas em menores (Fenech, 2001).

A relutância em voltar a criminalizar e punir exemplarmente, como se de adultos se tratassem, actos criminosos cometidos por menores, sendo ética e cientificamente inatacável, tem permitido que a representação de que a maioria dos criminosos, menores ou não, não é exemplarmente punida, se associe a uma outra, que se baseia na convicção, aparentemente crescente num número mais ou menos vasto de actores, de que apenas podem contar consigo mesmos para garantir a protecção e a segurança dos seus corpos e bens. Salientamos, no entanto, que a representação de que só uma punição exemplar do criminoso permite restituir alguma tranquilidade e segurança a uma vítima, ou a uma comunidade, nem sempre tem encontrado a necessária sustentação empírica. Pelo contrário, tem-se vindo a verificar que as vítimas de crimes nem sempre exigem, como forma de reparação ou de compensação pelos danos causados, uma punição exemplar do infractor ou agressor, invariavelmente traduzida numa pena de prisão efectiva.

Um elevado número de pesquisas ${ }^{20}$ tem mostrado, por exemplo, que as vítimas não tendem a ser mais punitivas que as não vítimas. Pelo contrário, muitas vezes sugerem espontaneamente sanções não punitivas, como uma compensação directa pelos danos causados, ou como o trabalho, não remunerado, a favor da comunidade. Outras pesquisas (Lee, 1994: 4-8, ou Roberts, 1992: 99-180) têm também mostrado que, embora se detecte uma preferência, em sondagens genéricas à opinião pública, por punições severas dos criminosos, essas mesmas punições tendem a ser substituídas por formas de reparação ou de compensação directa, sempre que estão em causa casos concretos. Isto é, sempre que os inquiridos foram, eles próprios, vítimas do crime em análise, ou sempre que é fornecida informação detalhada sobre o autor do crime ou sobre as circunstâncias em que o mesmo ocorreu.

Nesta sequência, tudo indica que a aparente preferência por punições muito severas para os criminosos, como a pena de prisão perpétua ou mesmo a pena de morte, tende a decorrer de uma necessidade difusa de segurança, necessidade que deixa de produzir efeitos sempre que os criminosos, em geral, dão lugar a seres humanos, reais, e a crimes, também eles reais. A exigência de que o sistema de justiça puna exemplarmente os crimi-

\footnotetext{
${ }^{19}$ Cerca de um em cada três autores de delitos são, na maioria das sociedades ocidentais, menores, de acordo com os dados referidos por Adler, F. et al. (1995).

${ }^{20}$ Cf. Boers, K. e Sessar, K. (1991), "Do People Really Want Punishment? On The Relation Between Acceptance Of Restitution, Needs for Punishment, and Fear of Crime", in Sessar, K. e Kerner, H. (Eds.), Development In Crime and Crime Control Research, New York, Verlag, ou Hough, M. e Moxon, D. (1985), "Dealing With Offenders: Popular Opinion and the Views of Victims in England and Wales", in Walker, N. e Hough, M. (Eds.), Public Attitudes to Sentencing: Surveys From Five Countries, Aldershot, Gower Publishing Co.
} 
nosos só parece ocorrer, na verdade, quando estão em causa crimes ou criminosos particularmente violentos. Quando estão em causa pequenos delitos, como os cometidos por jovens, ou a generalidade dos crimes contra o património, a maioria dos actores tem-se mostrado favorável ao recurso a formas directas de reparação ou compensação dos danos causados. Quer seja através de pagamentos directos à vítima, quer seja através da prestação de serviços à comunidade em geral ${ }^{21}$. Na maioria dos casos analisados, a prestação de serviços não remunerados à comunidade tem sido apontada, por exemplo, como a mais adequada forma de reparação ou de compensação, mesmo quando estão em causa crimes cometidos por autores reincidentes (Cf. Van Dijk, J., 1992).

\section{Que Estratégias de Prevenção Crimi- nal e de Redução da Insegurança?}

Uma parte significativa da insegurança revelada em meios urbanos parece poder ser reconduzida, de acordo com o que até aqui referimos, não a uma elevada ou crescente prevalência de comportamentos interpessoais violentos, mas a uma relativa saturação de incivilidades e de pequenos crimes. Ela parece ainda poder ser reconduzida, neste contexto de relativa saturação, a representações que colocam a génese da violência e do crime na existência de espaços urbanos perigosos, porque ocupados maioritariamente por actores quase inevitavelmente criminosos, e na relativa incapacidade do Estado para assegurar a protecção de pessoas e de bens, a detecção e o jul- gamento dos criminosos e a punição destes em função dos danos causados.

Nesta sequência, não surpreende que a maioria dos inquiridos na área metropolitana de Lisboa refira sistematicamente que se sente insegura por existir pouco policiamento e por residir na imediação de espaços perigosos ${ }^{22}$ (Quadro n. ${ }^{0} 1$ ). E que sugira, como principais e quase únicas medidas para reduzir a criminalidade e a insegurança revelada, mais policiamento e medidas judiciais mais severas, ou a desarticulação dos referidos espaços perigosos através de programas de redução da exclusão social, da toxicodependência ou do desemprego (Quadro n. ${ }^{\circ} 2$ ).

Quadro n. ${ }^{\circ} 1$ - Motivos da insegurança revelada na área de residência $(\mathrm{em} \%)^{23}$

\begin{tabular}{|l|r|}
\hline Existência de pouco policiamento & 41,6 \\
\hline Ocorrência de crimes & 35,6 \\
\hline Existência de pessoas com mau aspecto & 34,7 \\
\hline Pouca iluminação & 27,5 \\
\hline Existência de pessoas desocupadas & 20,1 \\
\hline Isolamento de alguns locais & 14,7 \\
\hline Existência de tráfico e consumo droga & 10,0 \\
\hline Locais perigosos & 9,1 \\
\hline Vitimação anterior & 8,3 \\
\hline Outros motivos & 2,5 \\
\hline
\end{tabular}

Fonte: Inquérito de Vitimação realizado pela Associação Portuguesa de Apoio à Vítima em 2001, no âmbito do Projecto Cíbele - Estudo sobre Prevenção do Crime e Vitimação Urbana.

\footnotetext{
${ }^{21}$ Cf. Hough, M. e Mayhew, P. (1985), Taking Account of Crime: Key Findings from the Second British Crime Survey (Home Office Research Study n. ${ }^{\circ}$ 85), London, Her Majesty's Stationary Office, London, Knowles, J. (1987), Ohio Citizens Attitudes Concerning Crime and Criminal Justice, Columbus, Office of Criminal Justice Services, Doob, A. e Roberts, J. (1988), "Public Punitiveness and Public Knowledge of the Facts: Some Canadian Surveys", in Walker, N. e Hough, M. (Eds.), Public Attitudes to Sentencing: Surveys from Five Countries, Aldershot, Gower Publishing Company, Adams, M. (1990), "Canadian Attitudes Toward Crime and Justice", Focus on Corrections Research, 2 (1), pp. 10-13, Bae, I. (1991), "A Survey on Public Acceptance of Restitution as an Alternative to Incarceration for Property Offenders in Hennepin County, Minnesota, USA, in Messmer, H. e Otto, H. (Eds.), Restorative Justice on Trial: Pitfalls and Potentials of Victim-Offender Mediation, Dordrecht, Kluwer Academic Publishers, pp. 291-307, Umbreit (1994), ou Lee, A. (1994), Ob. cit.

${ }^{22}$ Relativamente aos quais, curiosa mas teórica e empiricamente expectável, são evitadas referências directas a minorias sociais, culturais ou étnicas, referências essas apenas efectuadas por $0,6 \%$ dos inquiridos.

${ }^{23}$ Os totais e as respectivas percentagens são determinados individualmente por problema, dado tratar-se de um pergunta de escolha múltipla.
} 
Quadro n. ${ }^{\circ} 2$ - Medidas sugeridas para reduzir a criminalidade na área metropolitana de Lisboa (em \%)

\begin{tabular}{|l|c|}
\hline Mais policiamento & 70,7 \\
\hline Prevenção da exclusão social & 12,0 \\
\hline Prevenção da toxicodependência & 11,6 \\
\hline Medidas judiciais mais severas & 10,2 \\
\hline Mais emprego & 10,1 \\
\hline Recuperação de espaços verdes & 7,4 \\
\hline Controlar a imigração & 4,4 \\
\hline Mais civismo & 4,2 \\
\hline Outras medidas & 18,9 \\
\hline
\end{tabular}

Fonte: Inquérito de Vitimação realizado pela Associação Portuguesa de Apoio à Vítima em 2001, no âmbito do Projecto Cíbele - Estudo sobre Prevenção do Crime e Vitimação Urbana.

A elevada dependência da maioria dos actores urbanos relativamente à protecção e à segurança que é garantida pela polícia pode explicar os dois eixos em torno dos quais se estruturam as medidas, sugeridas pelos próprios inquiridos, para reduzir a criminalidade e, consequentemente, a insegurança revelada. No caso do primeiro eixo, que remete para uma actuação mais intensa e eficaz das autoridades policiais e judiciais, o que parece estar subjacente é o reconhecimento de que, após o longo processo civilizacional que colocou nas mãos do Estado o monopólio da violência legítima, à maioria dos actores urbanos pouco mais resta do que apelar à polícia e ao sistema de justiça penal para que cumpram mais eficazmente a sua função securitária.

Este apelo, que tem sido não raras vezes criticado como sendo disparatado ${ }^{24}$, não é, curiosamente, tão irracional ou ilógico como se poderia supor. A existência de um mais intenso e eficaz policiamento ${ }^{25}$ tem vindo a ser apontado, na verdade, como uma das poucas estratégias institucionais de prevenção criminal que apresenta resultados positivos, quer ao nível da redução de eventos, de vítimas ou de danos, quer ao nível da insegurança revelada. Em termos históricos, ou pelo menos desde o século XIX, detecta-se uma relação entre o aumento de efectivos policiais, e a sua maior preparação e competência, e a diminuição de crimes violentos, enquanto que as relações entre a evolução dos efectivos, a redução drástica dos mesmos em momentos específicos, a sua ausência em períodos de greve e os eventos criminais registados, mostram que estes tendem a ser mais reduzidos quando o número de efectivos é superior, sendo tal particularmente evidente em meios urbanos ${ }^{26}$.

Menos eficaz, entre as medidas que remetem para uma actuação mais intensa e eficaz das autoridades policiais e judiciais e pelo menos de acordo com as avaliações que têm sido efectuadas (Cf., entre outros, Byrne, Lurigio e Petersilia (s/d)), tem-se vindo a revelar o conjunto daquelas que remete para respostas punitivas clássicas, como a pena de prisão ${ }^{27}$. Com excepção do caso dos crimes mais violentos, cuja regressão tem sido relacionada com uma crescente intolerância relativamente à violência e com uma crescente opção pela detenção efectiva, e por períodos mais prolongados, dos agressores, as medidas que têm revelado resultados mais eficazes em termos de redução das incivilidades e da pequena criminalidade patrimonial são aquelas que remetem para o accionamento de uma justiça restaurativa, como já o salientámos anteriormente, ou para estratégias de prevenção situacional ${ }^{28}$. O facto de nenhuma destas medidas, invariavelmente bem sucedidas em termos de redução de eventos e de danos, bem como da insegurança relacionada com a relativa saturação de incivilidades e de pequenos crimes, ser referenciada por percentagens significativas dos actores, como se confirma no caso da área metro-

\footnotetext{
${ }^{24}$ No caso português, os comentários efectuados por um especialista aos resultados de uma sondagem à opinião pública são exemplares e ilustrativos: “(...) os resultados desta sondagem provam, mais uma vez, que as pessoas andam cheias de medo e, por isso, não estão a responder, como convém, com a cabeça fria. (...) O sentimento de segurança ou insegurança não é o resultado directo da criminalidade existente, de maior ou menor policiamento. (...)" in Diário de Notícias, 4 de Outubro de 1996, p. 31.

25 Porque direccionado para as áreas mais problemáticas e parcialmente aleatório em termos temporais.

${ }^{26}$ Cf., entre outros, Marvell, T. e Moody, C. (1996), "Specification Problems, Police Levels and Crime Rates", Criminoogy (34), pp. 609-646, Tonry, M. e Farrington, D. (Eds.), Building a Safer Society: Strategic Approaches to Crime Prevention. Crime and Justice (Vol. 19), Chicago, Universit of Chicago Press, Tonry, M. e Morris, N. (Eds.), Modern Policing. Crime and Justice (Vol. 15), Chicago, University of Chicago Press ou Monjardet, D., "Réinventer la police urbaine, Le travail policier à la question des quartiers", Les annales de la recherche urbaine, n. ${ }^{\circ} 83-84$.

27 Sendo mesmo particularmente problemáticas, como já o referimos, no caso da delinquência juvenil.

28 Sobre os fundamentos teóricos e alguns exemplos destas estratégias, bem como sobre os seus efeitos ver, por exemplo, Clarke, R. (Ed.), Situational crime prevention: successful case studies, Albany, Harrow and Heston.
} 
politana de Lisboa, pode ser explicado pela circunstância de serem quase totalmente contraditórias com o monopólio securitário e protector assumido e imposto pelo Estado ${ }^{29}$.

Quanto ao segundo eixo em torno do qual se estruturam as medidas, sugeridas pelos próprios inquiridos, para reduzir a criminalidade e, consequentemente, a insegurança revelada, medidas essas que remetem para a prevenção das causas mais prováveis da criminalidade, o que se tem vindo a verificar é que as mesmas têm produzido, com poucas excepções, resultados decepcionantes em termos de prevenção criminal ou de redução da insegurança revelada. As avaliações dos impactes de projectos que visam reduzir a prevalência de situações de desemprego ou de subemprego, de dependências de estupefacientes e de uma multiplicidade de outros factores de marginalização ou de exclusão social têm obtido resultados muito semelhantes, verificando-se que os mesmos contribuem efectivamente para uma reorganização social das áreas urbanas extremamente problemáticas, com significativos efeitos ao nível das oportunidades de educação, de formação e de emprego dos actores envolvidos e, consequentemente, dos níveis de exclusão e de marginalização social. No entanto, também se tem verificado que este tipo de projectos tem impactes muito pouco significativos sobre a redução da prevalência de comportamentos incivilizados ou criminosos e, consequentemente, sobre a insegurança urbana em geral (Cf. entre outros, Adler, F. et al., 1995 ou Tonry e Farrington, ( s/d).

\section{Uma Nota Final}

A insegurança que é hoje revelada por uma importante percentagem dos actores urbanos da maioria das sociedades ocidentais e, em particular, da área metropolitana de Lisboa, que tem sido inquirida em vários estudos de vitimação, reconduz-se a um complexo conjunto de factores em que ressalta uma relativa saturação de incivilidades e de pequenos crimes contra bens patrimoniais. Independentemente dos outros factores envolvidos, esta relativa saturação pode ser atenuada por algumas medidas de prevenção que não passam, necessariamente, pelas tradicionais respostas repressivas e punitivas do Estado. Quer a justiça restaurativa, quer algumas estratégias de prevenção situacional, têm-se revelado particularmente operativas a este nível, com a vantagem, não negligenciável no actual contexto socioeconómico e político, de evitarem uma ainda maior marginalização e estigmatização de actores urbanos já suficientemente marginalizados e estigmatizados. O problema, no entanto, reside no facto de estas medidas de prevenção ainda carecerem, em Portugal, de estudos de avaliação sistemáticos. Esta ausência tem impedido um debate público mais aprofundado e objectivo sobre a sua operatividade para a redução dos actuais níveis de insegurança urbana e esperamos que este artigo tenha contribuído, quer para um maior conhecimento desta problemática, quer para chamar a atenção para a necessidade urgente de estudos e debates mais aprofundados sobre a mesma.

\footnotetext{
${ }^{29}$ Quer a justiça restaurativa, quer as estratégias de prevenção situacional, pressupõem que cabe à comunidade uma parte importante na prevenção, na reparação dos danos causados ou na punição dos criminosos, pressuposto que choca frontalmente com aquilo que supostamente seria o culminar do processo civilizacional no campo da justiça penal.
} 


\section{Referências Bibliográficas}

ADLER, F. et al. ,1995, Criminology - The Shorter Version (second edition), McGraw-Hill.

ALMEIDA, M. e Alão, A.,1995, Inquérito de Vitimação de 1994, Lisboa, Gabinete de Estudos e Planeamento do Ministério da Justiça.

BAER, J. e Chambliss, W., 1997, "Generating fear: the politics of crime reporting", Crime, Law, and Social Change, 27, (2).

BANNISTER, J., 1993, "Locating fear: environment and ontological security", in Jones, H. (Ed.), Crime and the Urban Environment. The Scottish Experience, Avebury, Ashagate Publishing Company.

BEATTIE, J., 1986, Crime and the Courts in England, 1660-1800, New Jersey, Princeton University Press.

BECK, U., 1992, Risk Society, Towards a New Modernity, London, Sage Publications (edição original de 1982).

BYRNE, J., LURIGIO, A., e PETERSILIA, J. (Eds.), Smart sentencing: the emergence of intermediate sanctions, Newbury Park, Sage Publications.

CHIRICOS, T. et al, 1997, "Crime, news and fear of crime: toward identification of audience effects", Social Problems, $44,(3)$, pp. 342-357.

CUSSON, M., 1983, Le Contrôle Social du Crime, Paris, Presses Universitaires de France.

DAVIS, M.,1998, Ecology of Fear: Los Angeles and the Imagination of Disaster, New York, Vintage.

DIAS, J. e ANDRADE, M., 1984, Criminologia - o homem delinquente e a sociedade criminógena, Coimbra, Coimbra Editora, p. 286.

ELIAS, N., 1989, O processo civilizacional: investigações sociogenéticas e psicogenéticas, Lisboa, Dom Quixote.

ESTEVES, A.,1999, A criminalidade na Cidade de Lisboa, Lisboa, Edições Colibri.

FENECH, G., 2001, Tolerância Zero: Acabar com a criminalidade e a violência urbana, Lisboa, Editorial Inquérito.

FERNANDES, L.,1994, "Topografia urbana do medo: os espaços perigosos", Revista do Ministério Público, n. ${ }^{\circ} 59$.

FERREIRA, 1998, Crime e Insegurança em Portugal - padrões e tendências, Oeiras, Celta Editora.

FOUCAULT, M., 1977, Vigiar e Punir. História da Violência nas Prisões (5. ${ }^{\mathrm{a}}$ edição), Petrópolis, Editora Vozes.

GAROFALO, J.,1981, "The fear of crime: causes and consequences", Journal of Criminal Law and Criminology, 27, (2), pp. 839-859.

GERBNER, G e GROSS, L. ,1976, "Living with television: the violence profile", Journal of Communication, 26, pp. 172-199.
GERBNER, G., 1972, "Violence in television drama: trends and symbolic functions", in COMSTOCK, G. e RUBINSTEIN, E. (Eds.), Television and Social behavior: Media Content and Control (Vol. I), Washington, Government Printing Office.

HOFFER, P. e Hull, N., 1981, Murdering Mothers: Infanticide in England and New England, 1558-1803, New York, New York University Press.

JOHNSON, E. e MONKKONEN, E., 1996, The Civilization of Crime: Violence in Town and Country Since the Middle Ages, Chicago, University of Illinois Press.

KATZ, I e HASS, R.,1988, "Racial ambivalence and American value conflict: Co relational and priming studies of dual cognitive structures", Journal of Personality and Social Psychology, 55, pp. 893-905.

LAGRANGE, H. e ZAUBERMAN, R., 1991, "Introduction: du débat sur le crime et l'insecurité aux politiques locales", Déviance et Société, vol. 15, n. ${ }^{\circ} 3$, p. 243.

LANE, J. e Meeker, J., 2000, "Subcultural diversity and the fear of crime and gangs", Crime and Delinquency, 46

LEE, A.,1994, "Public Attitudes Towards Crime and Criminal Justice", Criminal Justice Quarterly, 8.

LODHI, A. e TILLY, C., 1973, "Urbanization, Crime and Collective Violence in Nineteenth Century France", American Journal of Sociology, 79.

MARVELL, T. e MOODY, C., 1996, "Specification Problems, Police Levels and Crime Rates", Criminoogy (34), pp. 609$-646$.

MAWBY, R. e BROWN, J., 1984, "Newspaper images of the victim: a British study", Victimology, 9, (1), pp. 82-94.

MILAVSKY, J. et al., 1982, Television and Aggression: A Panel Study, New York, Harper \& Row.

MONJARDET, D., "Réinventer la police urbaine, Le travail policier à la question des quartiers", Les annales de la recherche urbaine, $\mathrm{n}^{\circ}{ }^{8} 83-84$

MONTEIRO, M., 1999, “Meios de comunicação social e construção da realidade social”, Psicologia, Vol. XII (2).

PALMER, D,1996, "Determinants of Canadian attitudes toward immigration: more than just racism?" Canadian Journal of Behavioural Science, 28.

PERALVA, A.,1997, L'incivilité, la révolte et le crime. Violences juvéniles dans la société du risque, Paris, EHESS.

RÉMY, J. e VOYÉ, L., 1981, Ville, Ordre, et Violence, Paris, PUF.

RICO, J. e SALAS, L., 1988, Rico, J. e Salas, L.,1988, Inseguridad ciudadana y policía, Editorial Tecnos, Madrid.

ROBERT, P.,1990, "L'insécurité: représentations collectives et question pénale", L'année sociologique, 40, pp. 313-330. 
ROBERTS, J., 1992, "Public Opinion, Crime, and Criminal Justice", Crime and Justice A Review of Research, 16.

ROCHE, S., 1991, "L'insécurité: entre crime et citoyenneté", Déviance et Société, 15, (3), p. 14.

SIGNORIELLI, N., 1990, "Television's mean and dangerous world", in Signorielli, N. e Morgan, M. (Eds.), Cultivation Analysis. New Directions in Media Effects Research, Newbury Park, Sage Publications.

SKOCPOL, T., Bringing The State back, Cambridge, Cambridge University Press.

SPIERENBERG, P., 1996, "Long Term Trends in Homicide: Theoretical Reflections and Dutch Evidence, Fifteenth to Twentieth Centuries", in JOHNSON, E. e MONKKONEN, E., SANTOS, B. et al., 1996, Os Tribunais nas Sociedades Contemporâneas - o caso português, Porto, Afrontamento.

TILLY, C.,1985, "War making and state making as organized crime", in EVANS, P., RUESCHEMEYER, D. e TOURAINE, A. ,1991, Face à l'exclusion, Esprit.

TONRY, M. e FARRINGTON, D. (Eds.),(s/d), Building a Safer Society: Strategic Approaches to Crime Prevention. Crime and Justice (Vol. 19), Chicago, University of Chicago Press.

TONRY, M. e MORRIS, N. (Eds.) (s/d), Modern Policing. Crime and Justice (Vol. 15), Chicago, University of Chicago Press.
TYLER, T., 1984, "Assessing the risk of crime victimization: the integration of personal victimization experience and socially transmitted information", Journal of Social Issues, 40, (1).

VAN DIJK, J., 1992, Criminal Victimization in the Industrial World, The Netherlands, Directorate for Crime Prevention.

VAZ, M., 1998, Crime e Sociedade - Portugal na Segunda metade do século XIX, Oeiras, Celta Editora.

WARR, M., 1990, "Dangerous situations: social context and fear of victimization", Social Forces, 68, (3), pp. 891-907.

WEBER, M., 1983, A ética protestante e o espírito do capitalismo, Lisboa. Presença (Ed. original de 1904-5).

WELCH, M. et al., 2002, "Moral panic over youth violence: Wilding and the manufacture of menace in the media", Youth and Society, 34, (1).

WILLIAMS, P. e Dickinson, J., 1993, “Fear of crime: read all about it? The relationship between newspaper crime reporting and fear of crime", British Journal of Criminology, 33, (1).

WINKEL, F. e VRIJ, A., 1990, "Fear of crime and mass media crime reports - testing similarity hypotheses", International Review of Criminology, 1, (3), pp. 251-265.

WOBER, J., 1978, "Televised violence and paranoid perception: the view from Great Britain", Public Opinion Quaterly, 42. 